\title{
PROSES BERPIKIR SISWA DALAM MENYELESAIKAN SOAL KONTEKSTUAL HIMPUNAN DITINJAU DARI KECERDASAN LINGUISTIK DAN KECERDASAN LOGIS-MATEMATIS
}

\author{
Maidatuz Zulaihah \\ Program Studi Pendidikan Matematika, FMIPA, Universitas Negeri Surabaya \\ Maidatuzzulaihah16030174093@mhs.unesa.ac.id \\ Endah Budi Rahaju \\ Program Studi Pendidikan Matematika, FMIPA, Universitas Negeri Surabaya \\ endahrahaju@unesa.ac.id
}

\begin{abstract}
Abstrak
Penelitian ini bertujuan untuk mendeskripsikan proses berpikir siswa dalam menyelesaikan soal kontekstual himpunan ditinjau dari kecerdasan linguistik dan logis-matematis sehingga termasuk penelitian deskripstif kualitatif. Subjek yang diambil dalam penelitian ini yaitu empat siswa kelas VII yang terdiri dari dua siswa yang memiliki kecerdasan linguistik dan dua siswa yang memiliki kecerdasan logis-matematis. Pengumpulan data dilakukan dengan memberikan angket kecerdasan majemuk, tes matematika kontekstual yang diberikan kepada dua kelompok siswa linguistik dan logis-matematis, dan wawancara. Kemudian data dianalisis berdasarkan indikator proses berpikir siswa. Hasil penelitian ini menunjukkan, bahwa siswa dengan kecerdasan linguistik dapat mengingat dengan mengaitkan antara pengetahuan yang telah dimiliki dengan informasi pada soal yang dihadapi namun kurang tepat, mempertimbangkan informasi yang tidak diperlukan dan dua rencana yang akan digunakan yaitu rumus dan diagram venn, membuat argumen dengan menyebutkan kekurangan dan kelebihan setiap rencana yang dibuat namun kurang lengkap, dan memutuskan menggunakan satu cara yaitu ada yang menggunakan rumus dan ada yang menggunakan diagram venn kemudian menyimpulkan menggunakan bahasa yang sesuai soal. Sedangkan siswa dengan kecerdasan logismatematis juga dapat mengingat dengan mengaitkan antara pengetahuan yang telah dimiliki dengan informasi pada soal yang dihadapi dengan mengubah informasi soal ke bentuk simbol-simbol yang sesuai dengan pengetahuan sebelumnya, mempertimbangkan informasi yang tidak diperlukan dan dua rencana yang akan dipilih yaitu rumus dan diagram venn, membuat argumen dengan menyebutkan kekurangan dan kelebihan setiap rencana yang dibuat, dan memutuskan menggunakan satu cara yaitu ada yang menggunakan rumus dan ada yang menggunakan diagram venn kemudian menyimpulkan dengan menggunakan bahasanya sendiri.
\end{abstract}

Kata Kunci: proses berpikir, linguistik, logis-matematis, himpunan.

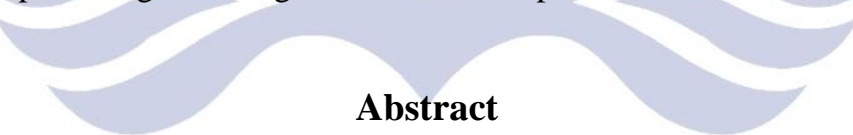

This study aims to describe the students' thought processes in completing sets of contextual problems in terms of linguistic and logical-mathematical intelligence so that it includes qualitative descriptive research. Subjects taken in this study were 4 grade VII students consisting of two students who had linguistic intelligence and two students who had logical-mathematical intelligence. Data collection was carried out by providing multiple intelligence questionnaires, contextual mathematics tests given to two groups of linguistic and logical-mathematical students, and interviews. Then the data are analyzed based on indicators of students' thought processes. The results of this study indicate, that students with linguistic intelligence can remember by linking the knowledge they have with information on the problem faced but it is not appropriate, considering unnecessary information and the two plans to be used namely the formula and venn diagram, making arguments by mentioning weaknesses and strengths of each plan made but incomplete, and decided to use one method that is using a formula and there are using venn diagrams and then conclude using the appropriate language problem. While students with logical-mathematical intelligence can also remember by linking the knowledge they have with information to the problem at hand by changing the problem information to the form of symbols that are in accordance with previous knowledge, considering unnecessary information and the two plans to be chosen namely Venn's formulas and diagrams, make arguments by mentioning the advantages and disadvantages of each plan made, and decide to use one method, there are those who use formulas and some use Venn diagrams and then conclude using their own language.

Keywords: the process of thinking, linguistic, logical-mathematical, the set. 


\section{PENDAHULUAN}

Berpikir merupakan suatu proses yang berlangsung secara alamiah oleh indivdiu. Nickerson (2014) menyatakan "in the fourth example think about means consider, and in fifth think could be replaced by reflect, ponder, and reason or deliberate". Berdasarkan pernyataan Nickerson (2014) berpikir memiliki makna paling sedikit empat istilah yaitu consider, reflect, ponder, dan reason. Consider yaitu mencari cara untuk menyelesaikan suatu permasalahan dengan cermat, mencari cara dalam arti memanggil kembali informasi yang berkaitan dengan permasalahan sehingga dapat diartikan sebagai mengingat. Ponder yaitu mempertimbangkan cara yang digunakan dengan cermat dan reason yaitu memberikan argumen terhadap cara yang digunakan. Alwi (2014) berpendapat bahwa proses berpikir adalah serangkaian aktivitas mental individu yang terjadi secara internal saat menyelesaikan suatu permasalahan. Serangkaian aktivitas mental meliputi mengingat, mempertimbangkan, membuat argumen, dan memutuskan sesuatu yang mengarah pada penyelesaian suatu persoalan.

Proses berpikir siswa sangat penting untuk diketahui oleh seorang guru. Guru dapat mengetahui proses berpikir siswa melalui hasil pekerjaan siswa dalam menyelesaikan soal. Seperti halnya pernyataan menurut Herbert (Herawati, 1994), bahwa untuk mengetahui proses berpikir siswa dapat diamati melalui cara menyelesaikan soal dan hasil yang ditulis secara terurut.

Berdasarkan pemaparan di atas, dalam penelitian ini yang dimaksud dengan proses berpikir adalah suatu aktivitas mental individu untuk memahami suatu persoalan sehingga memperoleh arahan untuk menyelesaikan persoalan tersebut. Aktivitas mental tersebut meliputi mengingat, mempertimbangkan, membuat argumen, dan membuat keputusan. Berikut indikator tahap proses berpikir yang merupakan adaptasi dari Alwi (2014) disajikan pada tabel 1 .

Tabel 1. Indikator Tahap Proses Berpikir

\begin{tabular}{|c|l|}
\hline $\begin{array}{c}\text { Tahap } \\
\text { Perpes }\end{array}$ & \multicolumn{1}{|c|}{ Indikator } \\
\hline \multirow{5}{*}{ Mengingat } & $\begin{array}{l}\text { Mengingat serta menjelaskan kembali } \\
\text { informasi yang diperoleh dari soal (hal } \\
\text { yang diketahui dan hal yang ditanyakan) }\end{array}$ \\
\cline { 2 - 3 } & $\begin{array}{l}\text { Mengingat konsep, operasi, atau rumus } \\
\text { diperoleh }\end{array}$ \\
\cline { 2 - 2 } & $\begin{array}{l}\text { Mengingat pengetahuan yang telah } \\
\text { dimiliki (pernah menyelesaikan soal yang } \\
\text { relevan) }\end{array}$ \\
\hline Mempertim \\
bangkan
\end{tabular} \begin{tabular}{l}
$\begin{array}{l}\text { Memilah-milah informasi yang tidak } \\
\text { diperlukan untuk merencanakan } \\
\text { penyelesaian soal }\end{array}$ \\
\hline
\end{tabular}

\begin{tabular}{|c|c|}
\hline $\begin{array}{c}\text { Tahap } \\
\text { Proses } \\
\text { Bernikir }\end{array}$ & Indikator \\
\hline & $\begin{array}{l}\text { Mempertimbangkan berbagai rencana } \\
\text { penyelesaian soal yang sesuai dengan } \\
\text { informasi yang diperoleh }\end{array}$ \\
\hline $\begin{array}{l}\text { Membuat } \\
\text { argumen }\end{array}$ & $\begin{array}{l}\text { Menjelaskan kekurangan dan kelebihan } \\
\text { dari berbagai rencana penyelesaian soal }\end{array}$ \\
\hline \multirow{3}{*}{$\begin{array}{c}\text { Memutus } \\
\text { kan }\end{array}$} & $\begin{array}{l}\text { Memutuskan cara penyelesaian soal yang } \\
\text { paling sesuai untuk memperoleh jawaban }\end{array}$ \\
\hline & $\begin{array}{l}\text { Melaksanakan cara penyelesaian yang } \\
\text { telah dipilih }\end{array}$ \\
\hline & $\begin{array}{l}\text { Membuat kesimpulan jawaban yang } \\
\text { diperoleh }\end{array}$ \\
\hline
\end{tabular}

Adapun adaptasi indikator tahap proses berpikir menurut Alwi (2014) yaitu (1) pada bagian mempertimbangkan, penelitian ini menambahkan indikator memilah informasi yang tidak diperlukan, (2) bagian membuat argumen, penelitian ini menggunakan indikator menjelaskan kelebihan dan kekurangan penggunaan setiap rencana yang akan dipilih dengan menghilangkan indikator Alwi karena pada penelitian ini sudah termasuk di bagian mempertimbangkan, dan (3) bagian memutuskan, penelitian ini menghilangkan indikator Alwi yaitu menceritakan kembali informasi yang diperoleh dan menambahkan membuat kesimpulan.

Soal yang digunakan untuk mengetahui proses berpikir siswa yaitu berupa soal kontekstual. Soal kontekstual merupakan soal yang dibuat berdasarkan kehidupan seharihari yang disajikan dalam bentuk soal cerita (Setiawani, 2017). Pada penelitian ini yang dimaksud dengan soal kontekstual adalah soal matematika yang dalam penyusunannya menggunakan konteks dalam lingkungan sekitar. Oleh karena itu dalam penelitian ini, soal kontekstual yang digunakan peneliti merupakan soal konteks dress-up yang berkaitan dengan sekolah/akademik. Soal konteks dress-up merupakan soal yang menggunakan bahasa cerita sehingga terasa bahwa soal tersebut memiliki konteks (De Lange dalam Pujiono, 2017).

Pada pembelajaran matematika, salah satu materi yang sering menggunakan soal kontekstual yaitu materi himpunan (Vahrum \& Rahaju, 2016). Berdasarkan penelitian Wimar (2016), terdapat beberapa kesulitan yang dialami siswa dalam materi himpunan. Kesulitan tersebut antara lain yaitu siswa kesulitan dalam memodelkan soal kontekstual ke dalam simbol matematika dan menentukan operasi himpunan yang sesuai. Begitu juga berdasarkan hasil Ujian Nasional tahun 2019, daya serap pada kompetensi himpunan sangat rendah yaitu $28.84 \%$.

Sesuai dengan penjelasan di atas, salah satu penyebab siswa kesulitan memahami pelajaran yaitu dikarenakan faktor kecerdasan siswa (Syah, 2009:184). Berdasarkan 
teori multiple intelligence menurut Gardner (Armstrong, 2009), setiap siswa memiliki delapan kecerdasan dalam kapasitas yang tidak sama. Gardner (Armstrong, 2009) menjelaskan terdapat delapan jenis kecerdasan, yaitu (1) verbal (linguistik), (2) visual, (3) logis-matematis, (4) musikal, (5) kinestetik, (6) intrapersonal, (7) interpersonal, dan (8) naturalis.

Saat menyelesaikan soal kontekstual matematika yang membutuhkan pemahaman, analisis, dan perhitungan terdapat tiga kecerdasan yang dibutuhkan yaitu kecerdasan linguistik, kecerdasan logis-matematis, dan kecerdasan visual-spasial (Nurhadiah, 2019). Sedangkan, dalam penelitian ini peneliti menggunakan materi himpunan sehingga terdapat dua kecerdasan yang dominan yaitu kecerdasan linguistik dan kecerdasan logis-matematis. Kecerdasan visual-spasial tidak dominan dalam materi himpunan karena pada materi himpunan hanya terdapat satu gambar yaitu diagram venn dan diagram venn ini tidak satu-satunya cara untuk menyelesaikan soal. Berikut penyataan dari Gardner (Armstrong, 2009) bahwa (1) "Linguistic: The capacity to use words effectively, whether orally (e.g., as a storyteller, orator, or politician) or in writing (e.g., as a poet, playwright, editor, or journalist)". Pernyataan tersebut menjelaskan bahwa kecerdasan linguistik yaitu kemampuan seseorang untuk menggunakan kata-kata secara efektif, baik secara lisan maupun tertulis dan (2) "Logical-mathematical: the capacity to use numbers effectively (e.g., as a mathematician, tax accountant, or statistician) and to reason well (e.g., as a scientist, computer programmer, or logician) ". Pernyataan tersebut menjelaskan bahwa kecerdasan Logis-matematis yaitu kemampuan seseorang untuk menggunakan angka secara efektif dan untuk bernalar dengan baik. Kemampuan bahasa yang baik berhubungan dengan kecerdasan linguistik. Begitu juga dengan kecerdasan logis-matematis yang digunakan untuk menghitung, membandingkan, dan menganalisis jawaban dari soal.

Penelitian ini relevan dengan penelitian oleh Ngilawajan (2013) dengan judul "Proses Berpikir Siswa SMA dalam Memecahkan Masalah Matematika Materi Turunan Ditinjau dari Gaya Kognitif Field Independent dan Field Dependent'. Penelitian oleh Ngilawajan (2013) terkait memecahkan masalah matematika ditinjau dari gaya kognitif Field Independent dan Field Dependent, sedangkan penelitian ini terkait soal kontekstual himpunan ditinjau dari kecerdasan linguistik dan logis-matematis. Penelitian ini juga relevan dengan penelitian oleh Nugroho (2013) dengan judul "Proses Berpikir Siswa dengan Kcerdasan Linguistik dan Kecerdasan Logis-matematis dalam Memecahkan Masalah Matematika”. Penelitian oleh Nugroho (2013) bertujuan untuk menunjukkan tipe proses berpikir siswa dengan kecerdasan linguistik dan logismatematis, sedangkan penelitian ini bertujuan untuk mendeskripsikan proses berpikir siswa ditinjau dari kecerdasan linguistik dan logis-matematis.

Berdasarkan uraian tersebut, peneliti memiliki dua pertanyaan penelitian antara lain, (1) bagaimana proses berpikir siswa dalam menyelesaikan soal kontekstual himpunan ditinjau dari kecerdasan linguistik? dan (2) bagaimana proses berpikir siswa dalam menyelesaikan soal kontekstual himpunan ditinjau dari kecerdasan logismatematis?.

\section{METODE}

Penelitian ini merupakan jenis penelitian deskriptif kualitatif yang bertujuan untuk mendeskripsikan proses berpikir siswa dalam menyelesaikan soal kontekstual himpunan ditinjau dari kecerdasan linguistik dan kecerdasan logis-matematis.

Sumber data penelitian ini yaitu siswa SMP kelas VII sebanyak 34 siswa di MTs Negeri Metatu Gresik. Subjek yang dipilih yaitu 4 siswa SMP kelas VII yang memenuhi kriteria. Kriteria subjek yang dipilih yaitu dua siswa yang memiliki kecerdasan linguistik dan dua siswa yang memiliki kecerdasan logis-matematis. Teknik pemilihan subjek penelitian ini dilakukan dengan memberikan angket kecerdasan majemuk kepada siswa kelas VII yang bertujuan untuk mengelompokkan siswa yang memiliki kecerdasan linguistik dan siswa yang memiliki kecerdasan logis-matematis. Selanjutnya, memberikan tes matematika kontekstual kepada kedua kelompok kecerdasan tersebut. Berdasarkan hasil tes matematika kontekstual, peneliti mengambil 4 siswa sebagai subjek penelitian yang terdiri dari satu siswa linguistik yang menjawab salah, satu siswa linguistik yang menjawab benar, satu siswa logismatematis yang menjawab salah, dan satu siswa logismatematis yang menjawab benar. Kemudian dilakukan wawancara kepada 4 subjek penelitian yang bertujuan untuk melengkapi data yang tidak terlihat dari jawaban tertulis subjek.

Teknik analisis data dilakukan berdasarkan indikator yang telah dibuat oleh peneliti seperti pada tabel 1 .

\section{HASIL}

Berikut rincian siswa yang tepilih sebagai subjek penelitian yang disajikan pada tabel.

Tabel 2. Subjek Penelitian

\begin{tabular}{|c|c|c|c|c|}
\hline No. & $\begin{array}{c}\text { Inisial } \\
\text { Nama }\end{array}$ & $\begin{array}{c}\text { Kecerdasan } \\
\text { Dominan }\end{array}$ & $\begin{array}{c}\text { Menjawab } \\
\text { (Benar/salah) }\end{array}$ & $\begin{array}{c}\text { Kode } \\
\text { Subjek }\end{array}$ \\
\hline 1. & ZUM & Linguistik & Salah & SL1 \\
\hline 2. & ELS & Linguistik & Benar & S12 \\
\hline 3. & LIL & $\begin{array}{c}\text { Logis- } \\
\text { matematis }\end{array}$ & Salah & SM1 \\
\hline 4. & ANI & $\begin{array}{c}\text { Logis- } \\
\text { matematis }\end{array}$ & Benar & SM2 \\
\hline
\end{tabular}

Berikut hasil dari tes matematika kontekstual dan wawancara 


\section{a. Subjek Linguistik yang Menjawab Salah (SL1)}

Subjek Linguistik yang pertama dapat menjawab soal dengan jelas namun hasil yang diperoleh salah. Berikut hasil tes matematika kontekstual oleh SL1.

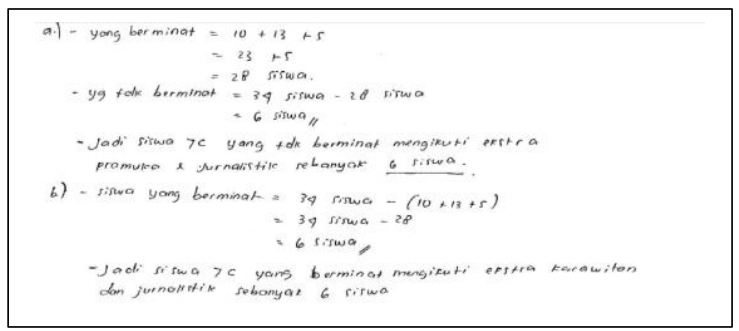

Gambar 1. Jawaban Tertulis Subjek SL1

Berikut ini disajikan kutipan transkrip wawancara dari SL1.

SL1 - 04P Coba jelaskan apa yang kamu ketahui dari soal

SL1 - 04S Itu menyatakan siswa kelas VII yang ada di sekolah SMPN 1 Gresik, terus siswa kelas VII C, 10 siswa mengikuti ekstrakurikuler pramuka, 13 siswa mengikuti ekstrakurikuler jurnalistik, sama 5 siswa mengikuti ekstrakurikuler pramuka dan jurnalistik

SL1 - 07P Kemudian apa yang ditanyakan dari soal tersebut?

SL1-07S Kelas VII C yang tidak berminat mengikuti pramuka dan jurnalistik sama kelas VII C yang berminat mengikuti karawitan atau renang

SL1 - 11P Soal ini termasuk materi apa?

SL1 - 11S Himpunan (mengingat, sebelum menjawab siswa lama terdiam), ada irisan dan gabungan

SL1 - 16P Apa kesamaan sama perbedaanya dengan soal ini? Coba jelaskan

SL1 - 16S Biasanya perbedaanya itu tidak ada siswa yang mengikuti pramuka dan jurnalistik, jadi sendiri-sendiri cuma ada yang ikut pramuka dan ada yang ikut jurnalistik

SL1 - 21P Adakah informasi yang tidak digunakan untuk menjawab soal?

SL1 - 21S Ada, seluruh siswa sekolah SMPN 1 Gresik yang ada 352 siswa

SL1 - 24P Untuk menjawab poin a dan b, kamu punya rencana apa saja?

SL1-24S Diagram sama yang saya gunakan ini (menunjuk lembar jawaban)

SL1 - 25P Bagaimana kamu bisa memperoleh dua rencana tersebut?

SL1 - 25S Tidak tahu (siswa lama terdiam)

SL1 - 27P Mengapa kamu tidak memilih diagram venn?

SL1 - 27S Karena saya lebih paham menggunakan cara seperti ini (menunjuk lembar jawaban). Kalau diagram venn paham tapi saya lupa

SL1 - 28P Baiklah, sekarang coba jelaskan bagaimana menjawab poin a?
SL1 - 28S Seluruh siswa kelas VIIC dikurangi yang minat, kan yang ditanyakan yang tidak berminat

SL1 - 35P Bagaimana dengan menjawab poin $b$ ?

SL1 - 35S Kan pertanyaannya yang berminat karawitan atau renang, berarti kan sama saja dengan siswa yang tidak berminat pramuka dan karawitan. Jadi hasilnya sama 6 siswa

Berdasarkan hasil jawaban tertulis dan wawancara dengan subjek SL1, pada proses mengingat subjek dapat mengingat informasi dari soal dengan menyebutkan hal yang diketahui namun kurang lengkap yaitu subjek tidak menyebutkan banyak siswa kelas VII di SMPN 1 Gresik dan banyak siswa kelas VII C (SL1-04S) dan dapat menjelaskan dengan benar hal yang ditanyakan (SL1 - 07S). Pada bagian ini subjek tidak menuliskan hal yang diketahui dan yang ditanyakan pada lembar jawaban. Subjek tidak dapat mengingat konsep yang sesuai dengan soal yang dihadapi karena subjek menyebutkan bagian dari konsep tersebut bukan keterkaitan dengan soal yang dihadapi (SL1-11S) serta subjek dapat mengingat pernah menyelesaikan soal yang serupa, perbedaannya yaitu soal sebelumnya tidak menyebutkan keduanya sedangkan soal ini menyebutkan siswa menyukai keduanya (SL1-16S).

Pada proses mempertimbangkan, subjek dapat memilah informasi yang tidak diperlukan untuk memperoleh jawaban yaitu 352 siswa kelas VII (SL121S) serta mempertimbangkan dua rencana yaitu rumus dan diagram venn (SL1-24S). Pada saat mempertimbangkan dua rencana tersebut, subjek ragu dalam memilih karena dari kedua rencana yang dipilih subjek tidak dapat mengaitkan dengan pengetahuan sebelumnya (SL1 - 25S).

Pada proses membuat argumen, subjek hanya dapat menyebutkan kelebihan dari rumus yang digunakan yaitu subjek lebih memahami menggunakan rumus karena kalau menggunakan diagram venn sebenarnya subjek paham namun lupa (SL1-27S).

Pada proses memutuskan, subjek memutuskan menggunakan rumus yang dibuat sendiri. Namun subjek mengalami miskonsepsi saat menjelaskan cara yang digunakan untuk menjawab poin a yaitu subjek menjelaskan bahwa seluruh siswa dikurangi dengan siswa yang berminat (SL1-28S) dan poin b yaitu siswa yang tidak berminat pramuka dan jurnalistik merupakan siswa yang berminat karawitan atau renang sehingga jawaban poin a dan poin b sama (SL1 - 35S). Oleh karena itu, kesimpulan yang dibuat oleh subjek salah karena subjek menggunakan rumus yang dibuat sendiri berdasarkan informasi yang diperoleh 
dari soal yang dihadapi tanpa mengaitkan dengan pengetahuan yang dimiliki yaitu materi himpunan. Pada bagian ini subjek menuliskan kesimpulan pada lembar jawaban.

\section{b. Subjek Linguistik yang Menjawab Benar (SL2)}

Subjek Linguistik yang kedua dapat menjawab soal dengan jelas dan benar. Berikut hasil tes matematika kontekstual oleh SL2.

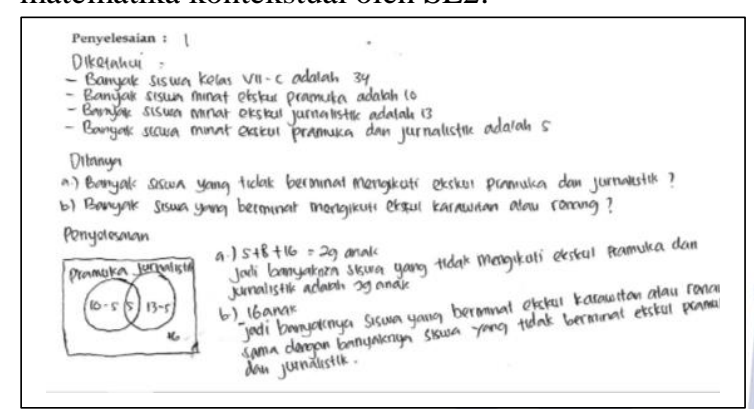

Gambar 2. Jawaban Tertulis Subjek SL2

Berikut ini disajikan kutipan transkrip wawancara dari SL1.

SL2 - 03P Coba jelaskan apa yang kamu ketahui dari soal

SL2 - 03S 10 siswa minat pramuka, 13 siswa minat jurnalistik, dan yang mengikuti keduanya ada 5 siswa. Sama kelas VII C ada 34 siswa

SL2 - 05P Soal tersebut menanyakan tentang apa?

SL2 - 05S Banyak siswa yang tidak minat pramuka dan jurnalistik dan banyak siswa yang minat karawitan atau renang

SL2 - 09P Soal ini termasuk kedalam bagian apa?

SL2 - 09S Irisan sama komplemen

SL2 - 11P Bedanya apa dengan soal ini?

SL2 - 11S Bedanya kalau soal yang pernah saya kerjakan itu menanyakan tentang irisan, sedangkan soal ini menanyakan tentang komplemen irisan

SL2 - 17P Adakah informasi yang tidak diperlukan untuk menjawab soal?

SL2 - 17S 352 siswa

SL2 - 20P Untuk menjawab poin a dan b, kamu punya rencana apa saja?

SL2 - 20S

SL2 - 21P

Rumus dan diagram ven

SL2-21S Rumus himpunan, saya ingat pernah mencatat rumus-rumus waktu pelajaran himpunan

SL2 - 24P Iyaa, dari dua rencana tersebut coba sebutkan kekurangan sama kelebihannya apa?

SL2 - 24S Kalau diagram venn mudah dan dilihat dari diagram venn saja sudah kelihatan jawabannya

SL2 - 25P Kalau menggunakan rumus, kekurangan sama kelebihannya apa?

SL2-25S Kalau menggunakan rumus terlalu banyak, saya juga lupa
SL2 - 26P Dari diagram venn sama rumus, kamu menggunakan cara apa untuk menyelesaikan soal ini?

SL2 - 26S Diagram venn

SL2 - 28P Bagaimana kamu membuat diagram venn ini? (menunjuk lembar jawaban)

SL2 - 28S Saya membuat persegi, kemudian saya membuat dua lingkaran di dalamnya yang berpotongan. Saya menuliskan pramuka sama jurnalistik di lingkaran tersebut. Kemudian saya isi setiap bagian di diagram venn, kan yang minat pramuka dan jurnalistik ada 5 jadi diisi dibagian yang berpotongan. Kemudian saya mengurangi dengan 5 dibagian pramuka dan dibagian jurnalistik.

Berdasarkan hasil tertulis dan wawancara dengan subjek SL2, pada proses mengingat subjek dapat mengingat informasi dari soal dengan menyebutkan hal yang diketahui namun kurang lengkap yaitu subjek tidak menjelaskan seluruh kelas VII ada 352 siswa (SL2 - 03S) dan hal yang ditanyakan pada soal yang dihadapi (SL2 - 05S). Pada bagian ini subjek juga menuliskan pada lembar jawaban. Subjek tidak dapat mengingat konsep yang sesuai dengan soal karena subjek menyebutkan bagian dari konsep tersebut (SL2 - 09S). Serta subjek dapat mengingat bahwa pernah menyelesaikan soal yang serupa dengan menyebutkan perbedaannya yaitu soal sebelumnya menanyakan tentang irisan sedangkan soal yang dihadapi menanyakan tentang komplemen irisan (SL2 - 11S).

Pada proses mempertimbangkan, subjek dapat memilah informasi yang tidak diperlukan untuk memperoleh jawaban yaitu seluruh siswa kelas VII sebanyak 352 siswa (SL2 - 17S ) serta mempertimbangkan dua rencana yaitu rumus dan diagram venn (SL2 - 20S). Pada saat mempertimbangkan dua rencana tersebut, subjek kelihatan yakin dapat menyelesaikan dengan tepat (SL2 - 21S)

Pada proses membuat argumen, subjek menjelaskan kelebihan dalam menggunakan diagram venn yaitu mudah dan jawaban dapat diperoleh melalui diagram venn apabila dapat membuat diagram venn dengan benar (SL2 - 24S) dan kekurangan dalam menggunakan rumus yaitu rumus yang digunakan terlalu banyak (SL2 - 25S).

Pada proses memutuskan, subjek memutuskan menggunakan diagram venn karena subjek lebih memahami dalam membuat diagram venn (SL2 26S). Subjek dapat membuat diagram venn dengan benar dan subjek menjelaskan bahwa subjek memberikan label pramuka dan jurnalistik pada dua lingkaran di diagram venn (SL2 - 28S). Saat 
menjawab poin a dan $\mathrm{b}$, subjek tidak mengalami kesulitan untuk memperoleh jawaban. Oleh karena itu, kesimpulan yang dibuat oleh subjek benar karena subjek mengaitkan dengan materi sebelumnya yaitu himpunan. Pada bagian ini subjek menuliskan kesimpulan pada lembar jawaban.

\section{c. Subjek Logis-matematis yang Menjawab Salah} (SM1)

Subjek Logis-matematis yang pertama dapat menjawab soal dengan jelas namun hasil yang diperoleh salah. Berikut hasil tes matematika kontekstual oleh SM1.

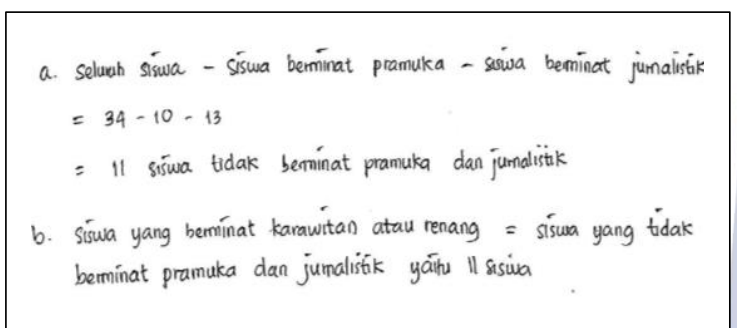

Gambar 3. Jawaban Tertulis Subjek SM1

Berikut ini disajikan kutipan transkrip wawancara dari SM1.

SM1 - 04P Coba jelaskan apa yang kamu ketahui dari soal

SM1 - 04S Pernyataan kelas VII ada 352 siswa, wali kelas VII C mendata ada 34 siswa, 10 siswa berminat mengikuti pramuka, 13 mengikuti jurnalistik, dan siswa yang ikut pramuka dan jurnalistik ada 5 siswa

SM1 - 05P Soal tersebut menanyakan tentang apa?

SM1-05S Banyak siswa yang tidak berminat pramuka dan jurnalistik sama banyak siswa yang berminat mengikuti karawitan dan renang

SM1 - 09P apa yang kamu ingat tentang himpunan?

SM1 - 09S (siswa lama terdiam sambil mengingatingat materi tersebut akhirnya mengatakan) irisan dan komplemen

SM1 - 15P Apa kesamaan dan perbedaan dengan soal ini?

SM1 - 15S Saya ingat biasanya ada diagram venn sama irisan

SM1 - 16P Diagram venn digunakan apa?

SM1 - 16S Untuk menyelesaikan

SM1 - 18P Adakah informasi yang tidak diperlukan untuk menjawab soal?

SM1 - 18S Ada, yang 352 siswa

SM1 - 21P Untuk menjawab poin a dan b, kamu punya rencana apa saja?

SM1 - 21S Diagram tapi saya bingung

SM1 - 22P Ada lagi tidak?

SM1 - 22S Sama ini cara yang saya gunakan

SM1-23P Darimana kamu mendapatkan cara tersebut?

SM1 - 23S Tidak tahu, saya kepikiran seperti itu

SM1 - 25P Mengapa kamu menggunakan cara ini (sambil menunjuk lembar jawaban siswa)
? Coba jelaskan kelebihan sama kekurangannya

SM1 - 25S Iya soalnya mudah

SM1 - 26P mengapa tidak memilih diagram venn?

SM1-26S Karena saya masih bingung kalau menggambar diagram venn

SM1 - 27P Coba kamu jelaskan bagaimana caranya kamu bisa mendapatkan jawaban poin a?

SM1 - 27S Yang ditanyakan di a kan siswa yang tidak berminat pramuka dan jurnalistik, berarti kan seluruh siswa dikurangi siswa yang berminat, berarti $34-10-13=$ 11

SM1 - 33P Bagaimana bisa jawabannya seperti a?

SM1 - 33S Iya, soalnya kan komplemen jadi semesta dikurangi yang minat pramuka dan jurnalistik jadi sisanya berminat karawitan dan renang

SM1 - 36P Dapatkah kamu menyimpulkan jawaban yang kamu peroleh?

SM1 - 36S Jawaban yang diperoleh dari poin a dan b sama yaitu 11 siswa

Berdasarkan hasil tertulis dan wawancara dengan subjek SM1, pada proses mengingat subjek dapat menyebutkan dengan tepat hal yang diketahui (SM1 04S) dan yang ditanyakan (SM1 - 05S) pada soal yang dihadapi, namun subjek tidak menuliskan pada lembar jawaban. Subjek juga dapat menjelaskan bahwa soal yang dihadapi sesuai dengan materi himpunan yaitu irisan dan komplemen (SM1 - 09S), namun kurang tepat yaitu subjek tidak menyebutkan bahwa soal tersebut termasuk kedalam gabungan dan komplemen irisan dari dua himpunan. Subjek juga mengingat bahwa soal tersebut serupa dengan soal yang pernah dikerjakan sebelumnya, perbedaan dengan soal yang dihadapi yaitu soal sebelumnya menanyakan tentang irisan (SM1 - 15S) dan diselesaikan menggunakan diagram venn (SM1 16S). Pada bagian ini, subjek tidak menyebutkan persamaan dengan soal sebelumnya.

Pada proses mempertimbangkan, subjek dapat memilah informasi yang tidak diperlukan untuk memperoleh jawaban yaitu 352 siswa (SM1 - 18S). Subjek juga memiliki dua rencana yang dapat dilakukan untuk memperoleh jawaban yaitu diagram venn (SM1 - 21S) dan rumus yang digunakan (SM1 22S). Subjek mencari rencana lain karena tidak paham dengan diagram venn, rencana tersebut yaitu rumus yang tidak diketahui diperoleh dari mana (SM1 - 23S).

Pada proses membuat argumen, subjek dapat menjelaskan kelebihan dari rumus yang digunakan yaitu lebih mudah dibandingkan diagram venn (SM1 - 25S), namun subjek tidak menjelaskan kekurangan dari rumus yang digunakan. Subjek juga menjelaskan kekurangan dalam menggunakan diagram venn yang 
dikaitkan dengan kemampuannya yaitu subjek kurang memahami dalam menggambar diagram venn (SM1 26S).

Pada proses memutuskan, subjek memutuskan menggunakan rumus yang merupakan caranya sendiri. Subjek mengalami miskonsepsi saat menjawab poin a dan poin $b$, saat menjawab poin a subjek mengurangi semesta dengan siswa yang berminat pramuka dan siswa yang berminat jurnalistik (SM1 - 27S). Sedangkan saat menjawab poin $b$, subjek dengan tanggap langsung menjawab bahwa hasil dari poin $b$ itu sama dengan poin a karena subjek menganggap bahwa siswa yang berminat karawitan atau renang merupakan sisa dari semesta dikurangi siswa yang berminat pramuka dan siswa yang berminat jurnalistik (SM1 - 33S). Sehingga kesimpulan poin a dan poin $b$ yang dibuat subjek salah karena subjek tidak mengaitkan dengan materi himpunan yang telah dipelajari. Pada bagian ini,subjek menyimpulkan dengan menggunakan bahasanya sendiri dan tidak menuliskan pada lembar jawaban (SM1 - 36S).

d. Subjek Logis-matematis yang Menjawab Benar (SM2)

Subjek Logis-matematis yang kedua dapat menjawab soal dengan jelas dan benar. Berikut hasil tes matematika kontekstual oleh SM2.

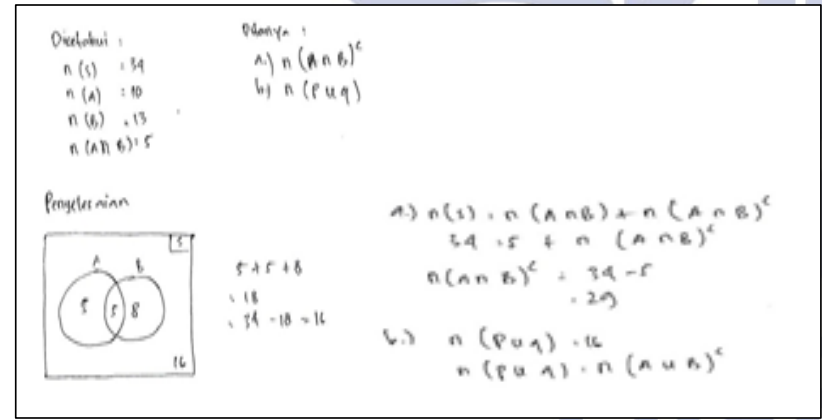

Gambar 4. Jawaban Tertulis Subjek SM2

Berikut ini disajikan kutipan transkrip wawancara dari SM2.

SM2 - 08P Coba jelaskan apa yang kamu ketahui dari soal

SM2 - 08S Kelas VII ada 352 siswa, kelas VII C ada 34 siswa, 10 siswa ikut pramuka, 13 siswa ikut jurnalistik, sama 5 siswa ikut pramuka dan jurnalistik

SM2 - 09P Soal tersebut menanyakan tentang apa?

SM2 - 09S Banyak siswa VII C yang tidak berminat pramuka dan jurnalistik sama banyak siswa VII C yang berminat mengikuti karawitan dan renang

SM2 - 18P Soal ini termasuk materi apa?

SM2 - 18S Irisan, gabungan, komplemen

SM2 - 22P Sekarang soal yang sama dengan soal ini seperti apa?
SM2 - 22S Sama tentang ekstrakurikuler (Berpikir)

SM2 - 25P Perbedaannya apa?

SM2 - 25S Bedanya menggunakan diagram venn, sedangkan soal ini tidak menggunakan diagram venn

SM2 - 29P Informasi mana yang tidak diperlukan?

SM2 - 29S Yang seluruh siswa kelas VII 352 siswa saja

SM2 - 32P Untuk menjawab poin a dan b, kamu punya rencana apa saja?

SM2 - 32S Diagram venn sama menggunakan rumus

SM2 - 34P Dari mana kamu bisa memiliki cara diagram venn sama rumus?

SM2 - 34S Kalau diagram venn saya masih ingat seperti dulu saya mengerjakan menggunakan diagram venn

SM2 - 35P Mengapa kamu memilih diagram venn? Kelebihan sama kekurangannya apa?

SM2 - 35S Karena mudah, saya tidak perlu menggunakan rumus yang panjang tapi saya harus benar-benar paham

SM2 - 37P Apa kelebihan dan kekurangannya menggunakan rumus?

SM2 - 37S Sudah pasti, tapi saya sulit untuk menghafal

SM2 - 39P Bagaimana cara membuat diagram venn?

SM2 - 39S Jadi, saya harus mengisi di setiap bagian diagram venn. Saya menyimbolkan pramuka sebagai A, jurnalistik sebagai B. kemudian saya mengisi setiap bagian, awalnya saya menulis angka 5 yang merupakan irisan. Kemudian siswa yang hanya minat pramuka ada 5 karena dikurangi sama irisan, dan yang hanya minat jurnalistik ada 8 karena dikurangi sama irisan. 16 itu dari sisa semesta.

SM2 - 40P Berarti dari diagram venn ini kamu bisa menjawab soal poin a dan $b$ ?

SM2 - 40S Bisa, jadi jawaban yang poin a itu ada 29 siswa dan jawaban poin b itu ada 16 siswa

SM2 - 43P Misalkan dibuat kesimpulan pada poin a dan b bagaimana?

SM2-43S Jadi, siswa yang tidak berminat mengikuti pramuka dan jurnalistik ada 29 anak

Sedangkan, poin b itu siswa yang minat karawitan atau renang ada 16 anak

Berdasarkan hasil tertulis dan wawancara dengan subjek SM2, pada proses mengingat subjek dapat menyebutkan dengan tepat hal yang diketahui (SM2 08S) dan yang ditanyakan (SM2 - 09S) pada soal yang dihadapi. Subjek menuliskan hal yang diketahui dan yang ditanyakan pada lembar jawaban dengan menggunakan simbol-simbol yang sesuai dengan materi himpunan. Subjek juga dapat menjelaskan bahwa soal yang dihadapi termasuk kedalam materi himpunan bagian irisan, gabungan, dan komplemen (SM2 - 18S). Kemudian subjek mengingat bahwa pernah menyelesaikan soal yang serupa yang memiliki persamaan dan perbedaan.. Persamaan dari 
soal yang sebelumnya yaitu sama-sama tentang ekstrakurikuler (SM2 - 22S) dan perbedaannya yaitu soal yang dihadapi berupa soal cerita sedangkan soal sebelumnya berupa diagram venn (SM2 - 25S).

Pada proses mempertimbangkan, subjek dapat memilah informasi yang tidak digunakan yaitu seluruh siswa kelas VII sebanyak 352 siswa (SM2 29S). Subjek juga memiliki dua rencana yaitu diagram venn dan rumus (SM2 - 32S). Subjek kelihatan yakin dapat menyelesaikan dari salah satu rencana tersebut, karena subjek dapat mengaitkan dengan pengetahuan sebelumnya (SM2 - 34S).

Pada proses membuat argumen, subjek menjelaskan kelebihan dalam menggunakan diagram venn yaitu mudah dan tidak perlu menggunakan rumus yang panjang (SM2 - 35S), namun subjek tidak menjelaskan kekurangan dalam menggunakan diagram venn. Subjek juga dapat menjelaskan kelebihan dalam menggunakan rumus yaitu rurmus yang digunakan sudah pasti (SM2 - 37S), dan subjek juga menjelaskan kekurangan dalam menggunakan rumus yaitu dengan mengaitkan kemampuannya yang sulit menghafal.

Pada proses memutuskan, subjek memutuskan menggunakan diagram venn. Subjek dapat menjelaskan caranya menggambar diagram venn dengan menggunakan penyimbolan A dan B, subjek juga menyebutkan kata irisan bagi siswa yang minat pramuka dan jurnalistik (SM2 - 39S). Berdasarkan diagram venn tersebut, subjek dapat memperoleh jawaban dari poin a dan poin b (SM2 - 40S). Subjek yakin bahwa jawaban yang diperoleh yaitu benar. Pada bagian ini subjek tidak menuliskan kesimpulan pada lembar jawaban, namun subjek dapat menjelaskan secara langsung kesimpulan dari jawaban yang diperoleh (SM2 - 43S).

\section{PEMBAHASAN}

Berdasarkan hasil analisis tes matematika kontekstual dan wawancara dengan subjek penelitian. Pada proses mengingat, siswa dengan kecerdasan linguistik dapat menjelaskan kembali informasi yang diperoleh dari soal dengan menggunakan bahasa yang sesuai pada soal yang dihadapi. Siswa mengingat pernah menghadapi soal yang serupa dengan menyebutkan perbedaan dengan soal yang dihadapi. Serta siswa dapat mengingat konsep yang sesuai dengan soal yang dihadapi namun kurang tepat.

Pada proses mempertimbangkan, siswa dengan kecerdasan linguistik dapat menjelaskan informasi yang tidak diperlukan untuk menjawab soal yang dihadapi dan siswa dapat mempertimbangkan bahwa ada dua rencana yaitu rumus dan diagram venn yang dapat digunakan. Hal ini sesuai dengan pernyataan Gardner (dalam Davis, 2011) bahwa seseorang yang memiliki kecerdasan linguistik mampu menganalisis suatu informasi yang digunakan untuk menyelesaikan soal.

Pada proses membuat argumen, siswa dengan kecerdasan linguistik tidak dapat menjelaskan kelebihan dan kekurangan setiap rencana yang akan dipilih dengan lengkap dan siswa tidak mengaitkan dengan pengetahuan sebelumnya. Hal ini sesuai dengan penelitian yang dilakukan Koyan (2003) bahwa seseorang yang memiliki kecerdasan linguistik dapat mengaitkan informasi yang diperoleh terhadap ide-ide rencana yang dipikirkan namun tidak mengaitkan dengan pengetahuan sebelumnya.

Pada proses memutuskan, siswa dengan kecerdasan linguistik menggunakan bahasa yang sesuai dengan soal yang dihadapi. Hal ini sesuai dengan pernyataan Gardner (Armstrong, 2009) bahwa siswa yang memiliki kecerdasan linguistik yaitu cenderung memiliki kemampuan untuk menggunakan kata-kata secara efektif, baik secara lisan maupun tertulis. Sedangkan pada bagian ini, siswa SL1 menjawab dengan salah sedangkan siswa SL2 dapat menjawab dengan benar.

Sedangkan pada proses mengingat, siswa dengan kecerdasan logis-matematis dapat menjelaskan kembali informasi yang diperoleh dari soal dengan mengubah ke bentuk simbol-simbol matematika yang sesuai. Siswa mengingat pernah menghadapi soal yang serupa dengan menyebutkan persamaan dan perbedaan dengan soal yang dihadapi. Serta siswa dapat mengingat konsep yang sesuai dengan soal yang dihadapi dengan tepat. Hal ini sesuai dengan penelitian Nurhadiah (2019).

Pada proses mempertimbangkan, siswa dengan kecerdasan logis-matematis dapat menjelaskan informasi yang tidak diperlukan untuk menjawab soal yang dihadapi dan siswa dapat mempertimbangkan bahwa ada dua rencana yaitu rumus dan diagram venn yang dapat digunakan. Hal ini sesuai dengan penelitian yang dilakukan Hasanah (2013) bahwa seseorang yang memiliki kecerdasan logis-matematis mampu mengklasifikasikan tentang informasi-informasi yang diperoleh untuk digunakan dalam menyelesaikan suatu soal.

Pada proses membuat argumen, siswa dengan kecerdasan logis-matematis dapat menjelaskan kekurangan dan kelebihan menggunakan dua rencana tersebut. Hal ini sesuai dengan pernyataan Gardner (dalam Suparno, 2004:40) bahwa seseorang yang memiliki kecerdasan logis-matematis memiliki kemampuan dalam melakukan penalaran yang benar dan logis berdasarkan pernyataan atau dalil-dalil, sehingga dalam berargumen terdapat dasar dalam menyatakannya.

Pada proses memutuskan, siswa dengan kecerdasan logis-matematis sudah memutuskan lebih awal cara yang akan digunakan untuk menyelesaikan soal yang dihadapi 
pada proses mempertimbangkan. Hal ini sesuai dengan pernyataan Lwin (2008:43) bahwa kecerdasan logismatematis yaitu menggunakan suatu bilangan dan perhitungan, pola dan pemikiran logis dan ilmiah secara efektif. Oleh karena itu pada bagian ini, siswa SM1 menjawab dengan salah sedangkan siswa SM2 dapat menjawab dengan benar.

\section{PENUTUP}

\section{Simpulan}

Berdasarkan hasil penelitian dan pembahasan sebelumnya, maka dapat diambil kesimpulan yaitu sebagai berikut.

1. Proses Berpikir Siswa dengan Kecerdasan Linguistik dalam Menyelesaikan soal Kontekstual Himpunan

Siswa dengan kecerdasan linguistik mengingat dengan menyebutkan hal yang diketahui dan ditanya sesuai dengan informasi yang diperoleh. Siswa mengaitkan informasi dari soal dengan pengetahuan sebelumnya seperti materi yang bersesuaian dengan soal yang dihadapi dan soal serupa yang pernah dikerjakan. Kemudian siswa mempertimbangkan dengan memilah-milah informasi yang tidak diperlukan dan mempertimbangkan dua rencana penyelesaian yaitu diagram venn dan rumus. Selanjutnya siswa membuat argumen dengan menjelaskan kekurangan dan kelebihan terhadap penggunaan dua rencana tersebut yang akan dipilih satu untuk memperoleh jawaban. Siswa linguistik yang pertama mengalami miskonsepsi dalam menggunakan rumus untuk menjawab poin $a$ dan $b$ yaitu banyaknya siswa yang tidak berminat pramuka dan jurnalistik diperoleh dari seluruh siswa kelas VIIC dikurangi siswa yang berminat pramuka, jurnalistik, dan berminat pramuka dan jurnalistik, serta banyak siswa yang berminat karawitan atau renang sama dengan banyak siswa yang tidak berminat pramuka dan jurnalistik. Sehingga kesimpulan poin a dan $b$ salah karena siswa hanya mengaitkan dengan informasi yang diperoleh dari soal yang dihadapi tidak dengan pengetahuan sebelumnya. Sedangkan siswa linguistik yang kedua menggunakan diagram venn. Saat menjawab poin a dan $b$, siswa dapat menjelaskan dalam membuat diagram venn dengan benar dan mengaitkannya dengan pengetahuan sebelumnya yaitu membuat dua lingkaran di dalam diagram venn yang berpotongan dalam materi himpunan disebut irisan. Sehingga kesimpulan poin a dan $\mathrm{b}$ benar karena siswa menjumlahkan semua nilai kecuali irisan yang ditunjukkan pada diagram venn. Saat membuat kesimpulan siswa linguistik lebih menuliskan menggunakan bahasa yang sesuai dengan informasi dari soal yang dihadapi.
2. Proses Berpikir Siswa dengan Kecerdasan Logismatematis dalam Menyelesaikan soal Kontekstual Himpunan

Siswa dengan kecerdasan logis-matematis mengingat dengan cara menyebutkan hal yang diketahui dan ditanya dengan mengubah informasi yang diperoleh dari soal menjadi simbol-simbol yang berkaitan dengan konsep himpunan. Siswa mengaitkan informasi dari soal dengan pengetahuan sebelumnya seperti materi yang bersesuaian dengan soal yang dihadapi dan soal serupa yang pernah dikerjakan. Kemudian siswa mempertimbangkan dengan memilah-milah informasi yang tidak diperlukan dan mempertimbangkan dua rencana penyelesaian yaitu rumus dan diagram venn. Selanjutnya siswa membuat argumen dengan menjelaskan kekurangan dan kelebihan terhadap penggunaan rumus dan diagram venn yang akan dipilih satu untuk menjawab soal. Siswa logismatematis yang pertama menggunakan rumus, siswa mengalami miskonsepsi pada poin a dan b yaitu banyak siswa yang tidak berminat pramuka dan jurnalistik diperoleh dari mengurangkan semesta dengan siswa yang berminat pramuka dan siswa yang berminat jurnalistik serta banyaknya siswa yang berminat karawitan atau renang sama dengan banyaknya siswa yang tidak berminat pramuka dan siswa yang tidak berminat jurnalistik. Sehingga kesimpulan poin a dan $b$ yang dibuat siswa salah karena siswa menjelaskan bahwa banyaknya siswa yang tidak berminat pramuka dan jurnalistik yaitu siswa yang berminat selain pramuka dan jurnalistik. Siswa logis-matematis yang kedua menggunakan diagram venn. Sebelumnya siswa membuat diagram venn terlebih dahulu, kemudian siswa dapat menjawab poin a dan b. Saat menjelaskan dalam pembuatan diagram venn, siswa mengaitkan dengan pengetahuan yang dimiliki yaitu dengan mengubah informasi pada soal ke bentuk simbol-simbol yang sesuai dengan materi sebelumnya yaitu himpunan. Diagram venn yang dibuat siswa sudah benar. Sehingga saat menjawab poin a dan $b$, siswa dapat menunjukkan banyaknya siswa yang tidak berminat pramuka dan jurnalistik yaitu dengan menjumlahkan semua bagian pada diagram venn kecuali nilai irisannya serta siswa dapat menunjukkan banyaknya siswa yang berminat karawitan atau renang dengan menjelaskan bahwa nilainya berada di luar lingkaran diagram venn karena lingkaran tersebut mewakili siswa yang berminat pramuka dan siswa yang berminat jurnalistik. Pada bagian ini siswa logismatematis mengubah informasi ke dalam simbolsimbol matematika yang sesuai dengan konsep 
himpunan. Saat membuat kesimpulan siswa logismatematis menjelaskan dengan menggunakan bahasa yang diubah ke dalam bahasa matematika.

\section{Saran}

Berdasarkan hasil penelitian yang telah diperoleh, peneliti memberikan saran kepada peneliti lain yang penelitiannya relevan dengan penelitian ini dan yang ingin mengembangkan penelitian ini. Berikut saran yang diberikan, (1) karena hasil penelitian ini menunjukkan ketidakpahaman siswa terhadap penggunaan rumus yang digunakan dan siswa cenderung menghafalkan rumus, jadi guru perlu berhati-hati dalam menyampaikan rumus-rumus pada himpunan dan (2) untuk mengembangkan penelitian ini subjek penelitian lanjutan dapat menggunakan jenis kelamin yang berbeda namun memiliki tipe kecerdasan yang sama sehingga peneliti dapat mengetahui perbedaan proses berpikir siswa, karena dalam penelitian ini menggunakan jenis kelamin yang sama sehingga cara berpikir siswa hampir sama.

\section{DAFTAR PUSTAKA}

Alwi. 2014. Proses Berpikir Siswa SMP dalam Menyelesaikan Masalah Kesebangunan Bangun Datar Ditinjau dari Perbedaan Kemampuan Matematika. Tesis tidak dipublikasikan. Surabaya: Universitas Negeri Surabaya.

Armstrong, Thomas. 2009. Multiple Intelligence in the Classroom 3rd Edition. USA: ASCD

Davis, Katie et al. 2011. The Theory of Multiple Intelligences. Online: http://papers.ssm (diakses 4 Oktober 2019 pukul 21.03)

Hasanah, Wardatul. \& Siswono, T. Y. E. 2013. Kecerdasan Logis-Matematis Siswa dalam Memecahkan Masalah Matematika pada Materi Komposisi Fungsi. Jurnal Matematika, MIPA: Universitas Negeri Surabaya.

Herawati, S. 1994. Penelusuran Kemampuan Siswa Sekolah Dasar dalam Memahami Bangun-bangun Geometri. (Studi Kasus di kelas V SD No. 4 Purus Selatan). Tesis tidak dipublikasikan. Malang: IKIP.
Koyan, I. W. 2003. Pengaruh Metode Pembelajaran Kooperatif dan Kemampuan Penalaran Verbal Terhadap Hasil Belajar Pendidikan Pancasila dan Kewarganegaraan (PPKn). Jurnal Pendidikan dan Pengajaran IKIP Negeri Singaraja, No. 1 TH. XXXVI Januari 2003. ISSN 0215-8250.

Lwin, May., dkk. 2008. How to Multiply Your Child's Intelligence. Yogyakarta: Indeks.

Nickerson, R. S., dkk. 2014. The Teaching of Thinking. New York: Psychology Press.

Nugroho, R.A. dkk. 2013. Proses Berpikir Siswa dengan Kecerdasan Linguistik dan Kecerdasan LogisMatematis dalam Memecahkan Masalah Matematika. JIPM. Vol. 2(3).

Nurhadiah. 2019. Proses Berpikir Siswa Ditinjau dari Kecerdasan Matematis logis dan Kecerdasan Linguistik Dalam memecahkan Masalah Matematika Materi SPLDV Kelas VIII di SMPN 1 Kauman Tulungagung. Tulungagung: Institut Agama Islam Negeri Tulungagung.

Pujiono. 2017. Proses Berpikir Siswa MA Dalam Membuat Peta Konsep Turunan Ditinjau Dari Gaya Belajar Visual, Auditori, Dan Kinestetik. Tesis tidak dipublikasikan. Surabaya: Universitas Negeri Surabaya.

Setiawani, Susi., dkk. 2017. Proses Berpikir Siswa Autis dalam Menyelesaikan Soal Kontekstual Matematika Dilihat dari Teori Suryabrata. Kadikma. Vol. 8(2)

Suparno, Paul. 2004. Teori Inteligensi Ganda dan Aplikasi di Sekolah. Yogyakarta: Kanisius.

Syah, Muhibbin. 2009. Psikologi Belajar. Jakarta: PT Raja Grafindo Persada.

Vahrum, F. N. \& Rahaju, E. B. 2016. Proses Berpikir Siswa SMP dalam Memecahkan Masalah Matematika Kontekstual pada Materi Himpunan Berdasarkan Gaya Kognitif Impulsive dan Reflective. JIPM. Vol. $3(5)$.

Wimar, P. F. N. 2016. Analisis Kesulitan Belajar Siswa pada Materi Himpunan di SMP Muhammadiyah 10 Surakarta IF TP 2015/2016. (Online), (http://eprints.ums.ac.id/48132/1/NASKAH\%20PUB LIKASI.pdf, diakses 19 September 2019 pukul 11.01) 